\title{
The ideas of students about neuroanatomy lesson at Sivas Cumhuriyet University Dentistry Faculty; analysis of the feedbacks
}

\section{Sivas Cumhuriyet Üniversitesi Diş Hekimliği Fakülttesi öğrencilerinin nöroanatomi dersi hakkındaki fikirleri; bir geribildirim analizi}

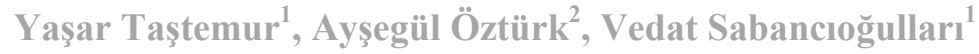

Sivas Cumhuriyet University Medical Faculty, Department of Anatomy, Sivas, Turkey

${ }^{2}$ Sivas Cumhuriyet University Medical Faculty, Department of Physiology, Sivas, Turkey

Corresponding author: Yaşar Taştemur, MD, Sivas Cumhuriyet University Medical Faculty, Department of Anatomy, Sivas, Turkey

E-mail: md.tastemur.yasar@gmail.com

Received/Accepted: September 29,2019/September 30, 2019

Conflict of interest: There is not a conflict of interest.

\section{SUMMARY}

Objective: In order to improve the quality of medical education, it is essential to learn the students' opinions about the lectures through surveys. For this reason, a questionnaire was applied to the 2nd and 3rd-year students of Dentistry students of Sivas Cumhuriyet University

Method: The study included 150 volunteer students ( 88 females and 62 males) who accepted to answer the questionnaire questions. A questionnaire consisting of 14 questions was applied to the students. The answers to the questionnaire questions were evaluated by using SPSS 23.0 program.

Results: $48 \%$ of the students stated that the neuroanatomy course should be taught in the first semester of the second year, and $54 \%$ stated that the neurophysiology course should be taught before the neuroanatomy course. While $45.3 \%$ of the students found the course content sufficient, $42.7 \%$ stated that it should be added to the curriculum in the clinical anatomy course. In addition, $14.7 \%$ of the students think that high-class size makes it challenging to learn practical courses such as neuroanatomy.

Conclusions: The feedback from the students shows that given the current content of the neuroanatomy course, it is more efficient to give the course in the second grade. In addition to the neuroanatomy course, the inclusion of neurophysiology and clinical anatomy courses in the curriculum will facilitate learning and be beneficial in improving the quality of education.

Keywords: Neuroanatomy, feedback, anatomy education
iD Yaşar Taştemur
(D) Ayşegül Öztürk
(D) Vedat Sabancioğulları

ORCID IDs of the authors: Y.T. 0000-0002-2016-0592 A.Ö. $0000-0001-8130-7968$ V.S. 0000-0001-9059-6554

\section{ÖZET}

Amaç: Eğitim kalitesinin arttırılmasında, öğrencilerin dersler hakkındaki düşüncelerini uygulanan anketler yoluyla öğrenmek önemlidir. Bu sebeple C.Ü. Diş Hekimliği 2.ve 3.sınıf öğrencilerine nöroanatomi dersinin yeterliliğini ve etkinliğini saptamak amacıyla anket uygulanmıştır.

Yöntem: Çalıșmaya anket sorularını cevaplamayı kabul eden 88'i kadın, 62'si erkek 150 gönüllü öğrenci dahil edildi. Öğrencilere 14 sorudan oluşan bir anket uyguland1. Anket sorularına verilen cevaplar, spss 23.0 programına yüklenerek değerlendirildi. 
Bulgular: Öğrencilerin \% 48’i nöroanatomi dersinin 2. sınıfin 1. döneminde okutulması gerektiğini, \% 54'ü ise nöroanatomi dersinden önce nörofizyoloji dersinin okutulması gerektiğini belirtmişlerdir. Öğrencilerin \%45,3’ü ders içeriğini yeterli bulurken, \%42,7'si klinik anatomi dersininde müfredata eklenmesi gerektiğini ifade etmişlerdir. Ayrıca öğrencilerin \%14,7'si sınıf mevcudunun yüksek olmasının nöroanatomi gibi uygulamalı derslerde öğrenmeyi zorlaştırdığını düşünmektedir.

Sonuç: Öğrencilerden alınan geribildirimler göstermektedir ki, nöroanatomi’nin mevcut içeriği gözönüne alındığında dersinikinci sınıfta verilmesi daha verimli olmaktadır. Ayrıca nöroanatomi dersinin yanısıra, nörofizyoloji ve klinik anatomi derslerinin müfredata dahil edilmesi öğrenmeyi kolaylaştıracak ve eğitimin kalitesinin arttırılmasında faydalı olacağı düșünülmektedir.

Anahtar sözcükler: Nöroanatomi, geri bildirim, anatomi eğitimi

\section{INTRODUCTION}

Anatomy is the branch of basic medicine which examines the organs that make up the human structure and shape, the systems formed by the organs coming together and their relations with each other ${ }^{1}$.

In the history of humanity, the desire to recognize and rule the human body has always existed. When the aesthetic values of the human body are combined with this desire, anatomy education has increased its importance.

Although all the information about human anatomy stacked up through history, and new methods to teach it, anatomy is one of the most difficult courses for students. Researchers who found that neuroanatomy, which is the sub-branch of anatomy, frightened students more, called this situation as "neuro-phobia". Isolating and showing the structures in the nervous system, their threedimensional locations, relative positions, functions, and diseases are among the factors that create difficulties for the students ${ }^{2}$.

The first study based on students' feedback was conducted in 1927 at Purdue University. Selin has determined that the attitude using student feedback forms in US schools raised over time ${ }^{3}$.

The reason for the frequent application of student feedback studies is to enable students to acquire a learning attitude that enables them to discover information through critical perception rather than passive learning ${ }^{4}$.

Gathering feedback about teaching training methods implemented by members and the views of interested parties allows collecting the ideas of all parties related to the process and enables to form health program evaluation and development process ${ }^{5}$.

In our country, people who graduated from the "Dentistry Faculty" get the title of "Dentist" with similar education programs European Union countries ${ }^{6}$.
In the Dentistry Faculty, Sivas Cumhuriyet University Anatomy Education starts at the second semester 1st grade, continues until 3rd year and ends with the topographic anatomy lesson. Neuroanatomy course is given mainly as theoretical and practical manner respectively at 2nd and 3rd grade.

As the knowledge gained through this course affects the success of oral, dental and maxillofacial surgery, in the present study, we aimed to evaluate the opinions of 2 nd and 3rdgrade students of Dentistry about neuroanatomy education with the help of a questionnaire.

\section{MATERIAL AND METHODS}

150 second and third-grade students who studying the nervous system anatomy course and accepted to answer the questionnaire questions at the Faculty of Dentistry of Cumhuriyet University in 2018 - 2019 academic year were included in present study. In the first part of the questionnaire, a personal information form consisting of 3 questions was included in order to obtain the demographic information of the participants. The questionnaire included 14 questions, 5 of which were Likert type. The students were not asked to write names on the questionnaire in order to express their ideas more clearly and objectively. In this way, it was aimed to increase the reliability of the research. The answers given to the questions were loaded into SPSS 23.0 program for statistical evaluation. Percentage and frequency values of the data were determined.

The following questions were included in the applied questionnaire form;

1. In which period should neuroanatomy be taught in order to be efficient?

2. What are the lessons to be taken before the neuroanatomy?

3. What are the problems in the learning process related to the neuroanatomy course? 
4. Is the duration of the neuroanatomy course sufficient?

5. What should the content of the neuroanatomy course be?

6. How should the theoretical course be handled?

7. Which of the following methods should be preferred for neuroanatomy practice exams?

8. In addition to the anatomy atlas images, photographs of the models in the laboratory should also be used in the narration of the theoretical courses.
9. Neuroanatomy course helps to understand what is needed to know professionally

10. During the laboratory applications, instructors should make models or cadavers.

11. Questions including visuals should be asked in the theoretical exams

12. The time given to answer each question is sufficient during the practice exam

13. The number of questions in the anatomy practice exam is sufficient

14. I believe attendance should be taken in neuroanatomy theoretical and practical courses.

\begin{tabular}{l}
\hline Table 1: Percentage distribution of students' answers to the survey questions \\
\hline
\end{tabular}

\section{RESULTS}

$88(58.7 \%)$ of the students included in present study were female and $62(41.3 \%)$ were male.

$68(45.3 \%)$ of the students were second grade and $82(54.7 \%)$ were third-grade students.

In order for the neuroanatomy course to be efficient, 72 (48\%) students wanted to be taught in the second year and the first term.

Before taking the neuroanatomy course, 81 (54\%) of the students reported that neurophysiology courses should be taken.

In the learning process related to neuroanatomy, $52(34.7 \%)$ of the students had an atlas, books and so on. $22(14.7 \%)$ thought that there were many students in the classroom, $30(20 \%)$ thought that visual and audio equipment was insufficient and 37 (24.7) thought that the students were not ready for class.

While $123(82 \%)$ of the students thought that the theoretical hours of the neuroanatomy course were sufficient, $19(12.7 \%)$ of them had to increase their theoretical hours, and $112(74.7 \%)$ of the students had sufficient time. 27 of them (18\%) stated that they should increase the practical course hours.

While the content of the course meets the expectations of $68(45.3 \%)$ students, 64 (42.7\%) students wish to add clinical anatomy courses.

$90(60 \%)$ students want to have oral expression, note-taking, and pp presentation together. In the neuroanatomy practice exams, $119(79.3 \%)$ of the students wanted to do the model and cadaver images by projecting them from the projector. 101 $(67.3 \%)$ students agreed that the photographs of the models in the laboratory should be used in addition to the anatomy atlas images. $75(50 \%)$ students participated in the idea that the neuroanatomy course helps to understand what they need to know professionally. 84 (56.0\%) students stated that they should definitely make a model or cadaver expression during the laboratory applications. 37 (24.7\%) students strongly agree that the questions including visuals should be asked in the theoretical exams, but $21(14.0 \%)$ students do not agree with that. 46 (30.7\%) students agreed that the time given to answer each 
question was sufficient during the practice exam. $70(46.7 \%)$ students stated that the number of questions in neuroanatomy practice exams was sufficient. $56(37.3 \%)$ students stated that they would attend neuroanatomy theoretical and practical courses even if no attendance was taken.

\section{DISCUSSION}

Nowadays, it is aimed that the student can direct himself/herself and gain independent learning skills in this direction. In line with this new understanding, educational evaluation processes are organized in such a way that the student is active. It is a frequently used way of correcting deficiencies and correcting mistakes by getting feedback from students about all subjects in the education process.

Although feedback studies are being conducted widely in the medical faculties for anatomy education, we think that there are not enough studies in the faculties of dentistry. This research has been organized with the aim of increasing the quality and efficiency of dental education considering this deficiency in the literature.

In present study, $48 \%$ (72) of the students stated that the neuroanatomy course should be taught in the first semester of the second year, and 54\% (81) reported that the neurophysiology course should be taught before the neuroanatomy course. The point of this question was to make the learning process easier and the place of the course in the curriculum and which lessons would be easier to take.

When we asked about the difficulties in the learning process, $34.7 \%$ (52) said that they could not reach the resources like an atlas, books and so on. beforehand. Uygur et al. In their study in the medical school, $86.1 \%$ of the students stated that they could not access atlas and resources. ${ }^{7}$. In another study conducted by Acuner et al., this rate was found to be $72.46 \%{ }^{8}$. Compared to these results, we find that students are better at accessing resources. However, considering today's conditions, we think that this ratio should be close to zero. We thought that more time should be devoted to guiding students in accessing resources. As another difficulty in the learning process, $30(20 \%)$ of the students stated that visual and audio equipment was insufficient. Gozil et al., found that the audiovisual tools used in the courses increased efficiency in $98.1 \%$ and $83.4 \%$ in a study conducted at Firat University ${ }^{9}$. Pulat Seren et al. stated that visual and auditory methods, which are used in health education, are important in maintaining persistence ${ }^{10}$. In the study by Otağ et al., $87 \%$ of the respondents argued that visual education should be given importance ${ }^{4}$. We have reached the findings supporting the idea that the visual side of the anatomy course is more important, furthermore, literature shows its importance clearly for a long time. Nonetheless, there are still things to be improved and addressed.

$22(14.7 \%)$ of our students stated that one of the learning difficulties is being more students than should be in the classroom. In a study conducted by Uygur et al., $86 \%$ of the students stated that the excess of class size negatively affected education ${ }^{7}$. In the study of Acuner et al., this rate was found to be $95.7 \%^{8}$. Based on all these results, in our opinion the increasing number of students has affected the situation negatively. we believe that the quotas should be taken into consideration in the opinions of the educators and educators.

Another difficulty in the learning process was the percentage of $37 \%$ (24.7) of the students who were not ready for class. In the study of Gözil et al., the rate of those who stated that it would be beneficial to give a lecture note on the subject was found to be over $80 \%$ and they stated that the giving lecture notes before the lesson would contribute to the course preparation process ${ }^{9}$. When we take into account these results, we come to a conclusion as the course process starts before the course. Presenting educational materials on the subject before the course is taught to reduce this problem.

$37(24.7 \%)$ students strongly agree with the questions that have visuals should be asked in the theoretical exams, $21(14.0 \%)$ students do not agree. According to the study by Tuygar et al., $44.4 \%$ of the answer to this question is positive ${ }^{11}$. It is striking that Ögetürk et al., found this rate as $\% 90^{12}$. One of the crucial inference from present study was the importance of the anatomy as visual learning and draws attention to the fact that visual recall is higher.

While the content of the course meets the expectations of $68(45.3 \%)$ students, 64 (42.7\%) students wish to add clinical anatomy courses. In the study of Ari et al., 90.1\% positive response was obtained when asked about the gain of anatomy education given with clinical information ${ }^{13}$. One of the subjects that are always discussed in the basic sciences courses is that the course cannot be understood at the time of the lecture. When combined with the clinic, in our opinion the usage area will settle in the student and increase the permanence and motivation to the lesson.

We believe that we have reached the guiding results in present study that aims to improve the 
education by taking the opinions of our students about the anatomy course that is given in the Dentistry Faculty of Sivas Cumhuriyet University. We consider the results of present study to be an example for other departments and universities.

\section{REFERENCES}

1. Çimen, Mehmet . Anatomi. Öz Emek Matbaasi ,2.Baski, SIVAS, 2017

2. Ilgaz, Hasan Barış. Temel nöroanatomi eğitiminde fibril diseksiyon, traktografi, mikroskobik anatomi ve plastinasyon tekniklerinin birlikte kullanim modeli oluşturulmasi. Doktora tezi, hacettepe üniversitesi sağlik bilimleri enstitüsü, Ankara, 2018

3. TUYGAR, Şeyda Ferah. Tip fakültelerinde mezuniyet öncesi anatomi eğitiminin öğrenci geribildirimleri ile değerlendirilmesi. Yüksek lisans tezi, Balikesir Üniversitesi, Sağlik Bilimleri Enstitüsü, Balikesir, 2014

4.OTAĞ İ, OTAĞ A. İnsan Anatomisi Ve Fizyolojisi Eğitimi Üzerine Öğrenci Görüşleri. Cumhuriyet International Journal of EducationCIJE e-ISSN: 2147-1606 Vol 2 (3), 2013, pp. 3945

5. Sarıkaya Ö, Gülpınar MA, Keklik D, Kalaça S. Öğrencilerin Sesini Dinlemek: Eğitimin Öğrenciler Tarafindan Değerlendirilmesi. Tip Eğitimi Dünyası Sayı: 9 Ekim 2002

6. Dişhekimliği eğitiminde mevcut durum ve sorunlar araştırması. Türk dişhekimleri birliği yayınları, araştırma dizisi 5, HAZİRAN 2008

7. Uygur R, Çağlar V, Topçu B, Aktaş S, Özen OA. The Assessment of the Students' Opinions about Anatomy Education Anatomi Eğitimi Hakkında Öğrenci Görüşlerinin Değerlendirilmesi. Int $\mathrm{J}$ Basic Clin Med 2013;1(2)94-106

8. Acuner AM, Yalçın M, Ersoy M, Tekdemir İ, Ersoy F. Ankara Üniversitesi Tip Fakültesi Anatomi dersine ilişkin öğretme-öğrenme sürecinin değerlendirilmesi. Ankara üniversites i tip

Fakültesi mecmuas i cilt 52, sayi 4, 1999 pp. 211218

9. R. Gözil, S. Özkan, M. Bahçelioğlu, D. Kadıŏlu, E. Çalgüner, H. Öktem, E. Şenol, M.S. Mutlu, A. Kürkçüoğlu, D. Yücel, T. Babuş. Gazi Üniversitesi Tip Fakültesi 2. Sinif öğrencilerinin anatomi eğitimini değerlendirmeleri. Tıp Eğitimi Dünyas1 Ekim 2006 Say1 23

10. Seren LP, Yakıncı C. Tip eğitiminde akılda kalıcılığg nasıl sağlarız? Çocuk Sağlığı ve Hastalıkları Dergisi 2015; 58: 123-130

11. Tuygar ŞF, Kuş İ, Gülcen B, Özcan E, Saygılı Ö. Tıp Fakültesi Öğrencilerinin Anatomi Sinavları ile İlgili Görüşleri. F.Ü.Sağ.Bil.Tıp Derg. 2015; 29 (1): 01 - 06

12. Öğetürk M, Kavaklı A, Kuş İ, Songur A, Zararsız İ, Sarsılmaz M. Tıp Öğrencileri Nasıl Bir Anatomi Eğitimi İstiyor? Tıp Eğitimi Dünyası Say1: 10 Ocak 2003

13. Arı İ, İrgi E, Kafa İM, Şendemir E. Bir Anket Çalışması: Anatomi Eğitimi ve Öğrencilerin Düşünceleri Uludağ Üniversitesi Tıp Fakültesi Dergisi. 29 (2): 15-18, 2003 